\title{
PELATIHAN BUDIDAYA CACING TANAH SEBAGAI USAHA ALTERNATIF DI MASA PANDEMI COVID-19 BAGI PENGURUS LEMBAGA TAHFIDZUL QUR'AN DI DUSUN WATES PRINGGARATA
}

\author{
Riana'), Malik Ibrahim ${ }^{1)}$ \\ 1)Prodi Sistem Informasi, Fakultas Tehnik, Universitas Nahdlatul Ulama NTB, Mataram, NTB, Indonesia \\ Corresponding author : Malik Ibrahim \\ E-mail : riana.ununtb@gmail.com
}

Diterima 08 April 2021, Direvisi 15 April 2021, Disetujui 15 April 2021

\begin{abstract}
ABSTRAK
Keadaan latar belakang ekonomi para wali santri rata-rata menengah kebawah sehingga tidak semua santri mampu membayar iuran bulanan yang dibebankan oleh pengurus yayasan. Apalagi pada saat pandemi seperti sekarang, banyak wali santri yang tidak ada pekerjaan sama sekali. Sehingga, pengurus Yayasan Daarul Hufadz Al-Amiin tidak bisa lagi memberikan tunjangan kepada para guru. Berdasarkan kondisi tersebut, kami ingin memberikan pelatihan budidaya cacing tanah kepada pengurus Yayasan Daarul Hufadz Al-Amiin, agar lembaga tahfizdul qur'an ini menjadi lembaga yang mandiri dari segi ekonomi. Di sisi lain, lokasi Yayasan Daarul Hufadz Al-Amiin ini berada tidak jauh dari pasar tradisional kecamatan pringgarata, sehingga banyak limbah sayuran yang bisa dimanfaatkan sebagai bahan untuk budidaya cacing tanah. Selain itu, kotoran ayam petelur dari pengusaha ayam petelur di sekitar Yayasan Daarul Hufadz Al-Amiin bisa digunakan sebagai bahan pakan cacing tanah. Kegiatan pengabdian ini dilaksanakan mulai dari kegiatan pelatihan yang diisi dengan pemberian materi dan praktek, pendampingan, monitoring dan evaluasi. Adapun peserta pelatihan yaitu semua pengurus Yayasan Daarul Hufadz Al-Amin dan para guru, para peserta sangat antusias dalam mengikuti pelatihan karena bagi mereka pelatihan budidaya cacing tanah ini adalah hal yang baru. Adapun beberapa materi pelatihan yaitu mulai dari pembuatan media, pemberian pakan, perawatan, hingga tehnik memanen. Pelatihan ini diakhiri dengan kegiatan pemberian bibit cacing tanah lumbrecus rubelus dari pihak pelaksana PKM kepada pengurus yayasan Daarul Hufadz Al-Amin sebagai modal awal untuk memulai usaha budidaya cacing tanah. Berdasarkan data hasil kegiatan PKM yang telah dilakukan dapat disimpulkan bahwa keterampilan berbudidaya cacing tanah sudah dilakukan dan pihak mitra mampu melaksanakan kegiatan tersebut meliputi persiapan media, pembuatan pakan, perawatan. Selain itu, hampir semua pengurus dari pihak mitra menyatakan bahwa pelatihan budidaya cacing tanah ini bermanfaat.
\end{abstract}

Kata kunci: budidaya; cacing tanah; pandemic covid-19; usaha alternatif.

\begin{abstract}
The state of the economic background of the guardians of the students is on average lower middle so that not all students can afford to pay monthly dues charged by the board of the foundation. No longer at a pandemic time like now, many parents have no job at all. Thus, the board of Daarul Hufadz Al-Amiin Foundation can no longer provide benefits to teachers. therefore, we want to provide training on the cultivation of earthworms to the board of Daarul Hufadz Al-Amiin Foundation, so that this qur'an tahfizdul institution becomes an independent institution in terms of economy. On the other hand, the location of Daarul Hufadz Al-Amiin Foundation is located not far from the traditional market of pringgarata subdistrict, so that a lot of vegetable waste can be used as an ingredient for the cultivation of earthworms. In addition, laying chicken manure from laying hen entrepreneurs around the Daarul Hufadz Al-Amiin Foundation can be used as feed material for earthworms. This devotional activity is carried out starting from training activities filled with materials and practices, mentoring, monitoring and evaluation. The participants of the training are all administrators of Daarul Hufadz Al-Amin Foundation and teachers, the participants are very enthusiastic in participating in the training because for them this earthworm cultivation training is a new thing. The training materials are ranging from media making, feeding, care, to harvesting techniques. This training ended with the activity of giving earthworm seeds lumbrecus rubelus from the implementing party of PKM to the board of the foundation Daarul Hufadz Al-Amin as the initial capital to start a business of earthworm cultivation. Based on the data of pkm activities that have been done can be concluded that the skills of earthworm cultivation has been done and the partners are able to carry out such activities including media preparation, feed making, maintenance. In
\end{abstract}


addition, almost all administrators from the partner side stated that this earthworm cultivation training is useful.

Keywords: cultivation; earthworms; pandemic covid-19; alternative business.

\section{PENDAHULUAN}

Yayasan Daarul Hufadz Al-Amiin merupakan salah satu lembaga tahfidz yang berada di dusun wates desa pringgarata kecamatan Pringgarata kabupaten Lombok tengah NTB, lembaga ini berdiri pada tahun 2015 dan mulai beropreasi pada tahun 2017. Sampai saat ini Yayasan Daarul Hufadz AlAmiin memliki hampir 350 santri (non mukim) yang terdiri dari berbagai usia mulai dari Taman Kanak-Kanak (TK) sampai dengan Madrasah Aliyah (MA/SMA), dengan capaian hafalan untuk tingkat MA/SMA 7 Juz sedangkan untuk tingkat TK dan SD 2 Juz.

Para guru/asaatidz merupakan hafidz qur'an yang rata-rata tidak memiliki pekerjaan tetap, untuk memberikan tunjangan kepada pada asaatidz pengurus menarik iuran sebesar Rp10.000/KK santri. Akan tetapi, karena keadaan latar belakang ekonomi para wali santri rata-rata menengah kebawah sehingga tidak semua santri mampu membayar iuran tersebut. Apalagi pada saat pandemi seperti sekarang, banyak wali santri yang tidak ada pekerjaan sama sekali. Sehingga, pengurus Yayasan Daarul Hufadz Al-Amiin tidak bisa lagi memberikan tunjangan kepada para asaatidz.

Berdasarkan kondisi tersebut, tim pelaksana PKM ingin memberikan pelatihan budidaya cacing tanah kepada pengurus Yayasan Daarul Hufadz Al-Amiin, agar lembaga tahfizdul qur'an ini menjadi lembaga yang mandiri dari segi ekonomi. Karena sekalipun ada program bantuan dari desa setempat untuk lembaga tahfidz, Yayasan Daarul Hufadz Al-Amiin tidak pernah mendapatkan program bantuan tersebut.

Di sisi lain, lokasi Yayasan Daarul Hufadz Al-Amiin ini berada tidak jauh dari pasar tradisional kecamatan pringgarata, sehingga banyak limbah sayuran yang bisa dimanfaatkan sebagai bahan untuk budidaya cacing tanah. Selain itu, kotoran ayam petelur dari pengusaha ayam petelur disekitar Yayasan Daarul Hufadz Al-Amiin bisa digunakan sebagai bahan pakan cacing tanah

Adapun tujuan dari kegiatan Pengabdian Kepada Masyarakat (PKM) ini yaitu memberikan pelatihan dan stimulus bagi pengurus Yayasan Daarul Hufadz Al-Amiin tentang bagaimana melakukan budidaya cacing tanah, sedangkan manfaat dari kegiatan Pengabdian Kepada Masyarakat (PKM) ini diharapkan dari pemberian pelatihan dan stimulus tentang bagaimana melakukan budidaya cacing tanah, lembaga Yayasan Daarul Hufadz Al-Amiin dapat menjadi lembaga yang mandiri secara ekonomi. Adapun sasaran dari kegiatan Pengabdian Kepada Masyarakat (PKM) ini khususnya kepada pengurus Yayasan Daarul Hufadz Al-Amiin, akan tetapi tidak menutup kemungkinan kepada masyarakat sekitarnya. Karena yayasan ini sering melibatkan masyarakat dalam setiap kegiatan berlangsung di Yayasan tersebut.

Cacing tanah digolongkan sebagai hewan invertebrata yang memiliki keunggulan dan potensi kegunaan yang luar biasa mengagumkan. Di antaranya untuk menjaga keseimbangan lingkungan, karena cacing tanah ini mempunyai kemampuan untuk memusnahkan bahan organik limbah ternak, atau limbah rumah tangga yang diubahnya menjadi bahan organik yang berguna untuk meningkatkan kesuburan tanah. Selain itu juga dapat digunakan sebagai salah satu alternatif pengganti tepung ikan, sebagai sumber protein hewani. $\mathrm{Di}$ samping Cacing tanah juga berpotensi sebagai dekomposer sampah, karena cacing ini dapat mempercepat proses penguraian sampah organik sehingga bermanfaat karena hasil dari pemeliharaan cacing tanah tersebut berupa kascing (bekas cacing) mempunyai kandungan bahan organiuk yang tinggi terutama $\mathrm{N}, \mathrm{P}$, dan $\mathrm{K}$. Budidaya cacing tanah sesungguhnya tidak memakan banyak waktu dan hanya menyediakan waktu memberi makanan dan memanennya saja. Tidak perlu membersihkan kandang dan sebagainya, seperti beternak hewan lain karena kotoran cacing akan berfungsi sekaligus sebagai pupuk organik yang berkualitas tinggi. Berdasarkan hal-hal tersebut, maka sangat baik apabila cacing ini dibudidayakan dan menjadi sumber pencahairan.

$\begin{array}{ll}\text { Deskripsi Cacing Tanah } \\ \text { Spesies } & : \text { Lumbricus rubellus } \\ \text { Genus } & : \text { Lumbricus } \\ \text { Family } & : \text { Lumbricidae } \\ \text { Ordo } & \text { : Oligochaeta } \\ \text { Class } & : \text { Chaetopoda } \\ \text { Phylum } & : \text { Annelida } \\ \text { Divisi } & : \text { Vermes } \\ \text { Kingdom } & : \text { Animal }\end{array}$

\section{METODE}

Kegiatan PKM ini diawali dengan penandatangan kontrak antara pelaksana PKM 
dengan pihak Yayasan Daarul Hufadz Al-Amiin, selanjutnya pada tanggal tanggal 6 Desember 2020 pelaksana PKM memberika pelatihan yang diisi dengan pemberian materi dan praktek.

\section{Materi}

1. Pemberian materi tentang cacing tanah.

2. Pemberian materi tentang budidaya cacing tanah

3. Pemberian materi tentang persiapan media cacing tanah.

4. Pemberian materi tentang pembuatan pakan untuk cacing tanah.

5. Pemberian materi tentang tata cara perawatan

6. Pemberian materi tentang teknik panen cacing tanah.

Ada banyak jenis cacing di muka bumi ini, tetapi tidak semua jenis cacing bisa dibudidayakan, adapun jenis cacing yang dibudidayakan pada kegiatan PKM ini yaitu: Cacing Lumbricus Rubellus. Cacing lumbricus rubellus atau biasa disebut red worm, karena tubuhnya berwarna merah kecoklatan, cacing mudah dibudidayakan karena cepat berkembangbiak, 1 indukan mampu menghasilkan 102 sampai dengan 106 telur atau kokon/tahun. Adapun ciri fisik dari jenis cacing ini yaitu:

a. Ukuran tubuh relatif kecil, dengan panjang tubuh $6-8 \mathrm{~cm}$.

b. Bentuk tubuh pipih \& bentuk ekor tumpul \& ujung ekor berwarna kuning.

c. Warna tubuh merah kecoklatan.

d. Gerakan lamban.

e. Mampu hidup dalam jumlah koloni yang padat.

f. Bertelur setiap 2 minggu sekali.

\section{Praktik}

1. Praktek pembuatan media untuk cacing tanah.

2. Praktek pembuatan pakan untuk cacing.

3. Prakter perawatan/pemeliharaan.

4. Prakter tata cara memanen

\section{Pendampingan, Monitoring dan Evaluasi}

Adapun kegiatan pendampingan, monitoring dan evaluasi mempuyai beberapa tujuan yaitu:

1. Melihat sejauh mana kemampuan mitra dalam melaksanaka budidaya cacing tanah

2. Memberikan solusi bagi pihak PKM jika ada kendala atau masalah yang dihadapi selama kegiatan budidaya cacing tanah

3. Memberikan saran dan masukan kepada pihak mitra agar hasil akhir kegiatan budidaya cacing tanah sesuai dengan harapan.

\section{HASIL DAN PEMBAHASAN}

Yayasan Daarul Hufadz Al-Amiin merupakan salah satu lembaga tahfidz yang berada di dusun wates desa pringgarata kecamatan Pringgarata kabupaten Lombok tengah NTB, lembaga ini berdiri pada tahun 2015 dan mulai beropreasi pada tahun 2017. Sampai saat ini Yayasan Daarul Hufadz AlAmiin memliki hampir 350 santri (non mukim) yang terdiri dari berbagai usia mulai dari Taman Kanak-Kanak (TK) sampai dengan Madrasah Aliyah (MA/SMA), dengan capaian hafalan untuk tingkat MA/SMA 7 Juz sedangkan untuk tingkat TK dan SD 2 Juz. Adapun pengurusnya terdiri tokoh agama dan tokoh masyarakat disekitar yayasan tersebut, kepengurusan terdiri dari Pembina, Pengawas, Ketua, Sekertarsi, dan Bendahara. Sedangkan para Asaatidz (guru) berjumlah 10 orang, semuanya merupakan warga di sekitar yayasan tersebut. Mata pencaharian pada asaatidz rata-rata adalah seorang petani.

\section{Pelaksanaan PKM}

Kegiatan PKM ini diawali dengan penandatangan kontrak antara pelaksana PKM dengan pihak Yayasan Daarul Hufadz Al-Amiin, selanjutnya pada tanggal tanggal 6 Desember 2020 pihak PKM mengikuti pelatihan budidaya cacing tanah yang dilaksanakan via zoom dengan tujuan agar pihak PKM bisa memberikan pendampingan kepada pihak yayasan Daarul hufadz al-amiin ketika melakukan budidaya cacing tanah. Selanjutnya, pihak PKM mengawali kegiatan PKM dengan memberikan pelatihan berupa materi kepada pengurus yayasan Daarul Hufadz Al-Amiin. Berikut beberapa dokumentasi tentang pelaksanaan PKM

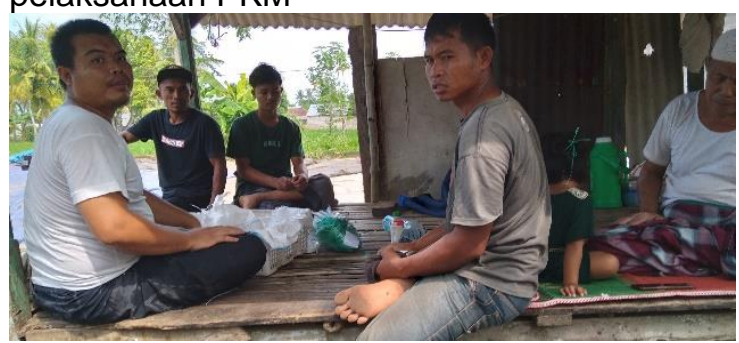

Gambar 1. Praktek pembuatan media cacing tanah

Gambar 1 di atas merupakan salah satu kegiatan praktek pembuatan media cacing tanah dengan menggunakan box buah-buahan kemudian dilapisi dengan bahan yang bisa menyerap air salah satu alternative yaitu karung seperti pada Gambar 2 di bawah ini 


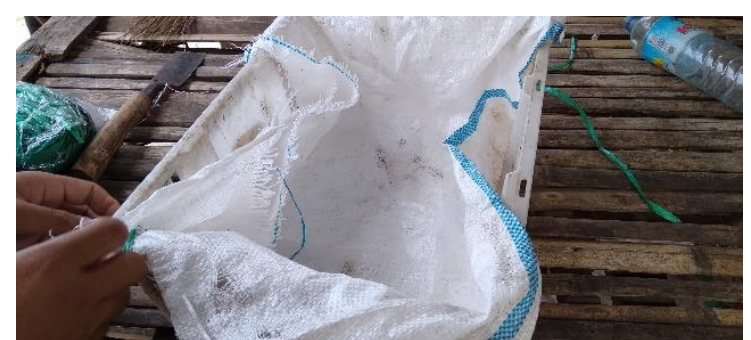

Gambar 2. Praktek pembuatan media cacing tanah

Untuk mengetahui respon pihak Yayasan daarul Hufadz tehadap kegiatan PKM ini, pelaksana memberika angket kepada pihak mitra. Tabel 1 berikut membeikan hasil angket respon pihak mitra tehadap kegiatan PKM

Tabel 1. Rekap Angket Respon Peserta Pelatihan Budidaya Cacing Tanah.

\begin{tabular}{llcc}
\hline \multirow{2}{*}{ Pertanyaan } & \multicolumn{2}{c}{ Jawaban } \\
\cline { 2 - 3 } 1. & Apakah bapak lbu & Tidak \\
pernah mendapat \\
pelatihan budidaya \\
cacing tanah?
\end{tabular}

\begin{tabular}{llll}
\hline 2. $\begin{array}{l}\text { Apakah menurut } \\
\text { Bapak Ib } 10\end{array}$ & 0 \\
pelatihan budidaya & & \\
cacing tanah & & \\
mudah dikerjakan & &
\end{tabular}

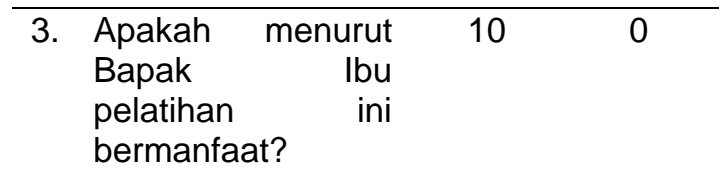

4. Apakah menurut $7 \quad 3$ Bapak lbu biaya untuk mengembangkan budidaya cacing tanah masih terjangkau?

5. Apakah menurut Bapak Ibu tertarik mengembangkan budidaya cacing tanah

6. Apakah Bapak lbu 9
menghendaki
pelatihan yang
lain?

7. Pelatihan Apa yang dikehendaki, tuliskan!
$\checkmark$ Pelatihan budidaya cacing jenis lain
$\checkmark$ Pelatihan pembuatan obat dari cacing

Pelatihan pembuatan kosmetik dari cacing tanah

Berdasarkan data pada Tabel 1 tersebut dapat dikatakan bahwa peserta pelatihan memberikan respon yang positif terhadap kegiatan PKM ini karena kegiatan pelatihan budidaya cacing tanah merupakan hal yang baru dan tidak terlalu sulit untuk dipraktekkan, selain itu modal dan kerugiannya juga sangat minim.

Kemampuan keterampilan berbudidaya cacing tanah para pesrta saat praktek diobservasi menggunakan lembar observasi keterampilan berbudidaya. Adapun hasil pengamatan kemampuan ketrampilan peserta disajikan pada Tabel 2.

Tabel 2. Data Hasil Observasi Ketrampilan Peserta Dalam Berbudidaya Cacing Tanah

\begin{tabular}{|c|c|c|}
\hline \multirow{2}{*}{ Aspek Penilaian } & \multicolumn{2}{|c|}{ Dilakukan } \\
\hline & Ya & Tidak \\
\hline $\begin{array}{l}\text { 1. Pembuatan media } \\
\text { cacing tanah }\end{array}$ & $100 \%$ & $0 \%$ \\
\hline $\begin{array}{l}\text { 2. Pembuatan pakan } \\
\text { cacing tanah }\end{array}$ & $100 \%$ & $0 \%$ \\
\hline $\begin{array}{l}\text { 3. Perawatan cacing } \\
\text { tanah }\end{array}$ & $70 \%$ & $30 \%$ \\
\hline $\begin{array}{l}\text { 4. Pemilahan cacing } \\
\text { tanah yang sudah } \\
\text { berkembang biak }\end{array}$ & $90 \%$ & $10 \%$ \\
\hline
\end{tabular}

Berdasarkan data pada Tabel 2 tersebut dapat dikatakan bahwa pihak mitra sudah mempunyai keterampilan yang cukup baik untuk melakukan budidaya cacing tanah, namun masih kurang dalam melakukan perawatan, hal ini dikarenakan pihak mitra mempunyai beberapa kegiatan intern lainnya. Berikut beberapa gambar hasil keterampilan pihak mitra dalam melakukan budidaya cacing tanah

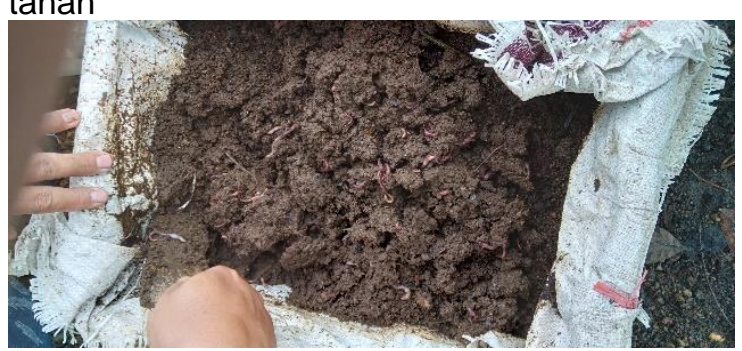

Gambar 3. Pengemburan media cacing tanah

Pengemburan media cacing tanah sepeti Gambar 3 merupakan salah satu cara merawat cacing tanah agar cacing tanah mendapatkan udara. Selanjutnya agar cacing dapat 
berkembang dengan maksimal dilakukan pemilahan cacing tanah seperti pada Gambar 4 di bawah ini

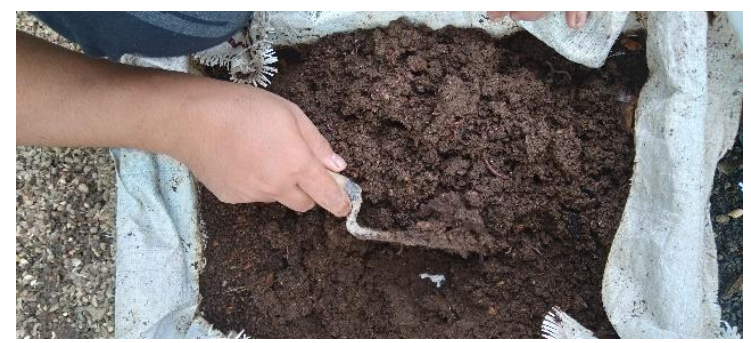

Gambar 4. Pemilahan cacing tanah

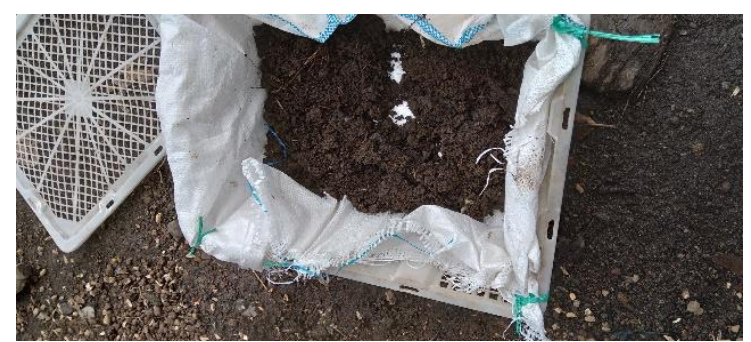

Gambar 5. Persiapan media setelah pemilahan

Gambar 5 di atas merupakan media yang dibuatkan untuk anak cacing Setelah dilakukan pemilahan antara induk cacing dengan anak cacing.

\section{Perkembangan Budidaya Cacing Tanah}

Untuk mengetahui perkembangan budidaya cacing tanah, dilakukan monitoring dan evaluasi oleh tim pelaksana PKM. Berikut adalah foto dokumentasi untuk kegiatan monitoring PKM.

Pada kegiatan ini diperoleh permasalahan-permasalahan yang dihadapi oleh peserta pelatihan antara lain:

1. Banyak cacing yang mati karena telalu lama dalam pengiriman

2. Banyak cacing yang mati karena tidak sesuai dengan media.

3. Hilangnya cacing karena keluar dari media.

4. Media yang terlalu padat.

5. Perawatan kurang maksimal.

Untuk menjawab dan mengatasi permasalahan tersebut, tim pelaksana PKM memberikan solusi secara umum antara lain:

1. Cacing keluar dari media, artinya cacing tidak cocok dengan medianya sehingga media harus diganti.

2. Jika media terlalu padat, maka perlu dilakukan pengemburan.

3. Pengemburan sebaiknya dilakukan secara berkala, dengan menggunakan tangan atau alat-alat yang tidak membahayakan cacing.

4. Perawatan yang kurang maksimal akan mengakibatkan Jika cacing kurus-kurus kemungkinan makanan tidak cocok, maka makanan bisa diganti dengan yang lain yang kaya protein.

5. Cacing hendaknya dipilah antara yang kecil dan yang besar sehingga dapat ditentukan mana yang bibit dan yang afkir sehingga dapat menentukan mana yang bisa dijual langsung sebagai pakan, sebagai bibit atau dijadikan bahan tepung.

Dari semenjak waktu diberikan bibit kepada mitra PKM yaitu pada akhir bulan desember tahun 2020 sampai dengan bulan maret 2021, cacing telah berkembang dari 2 box mejadi 4 box seperti pada Gambar 6 di bawah ini.

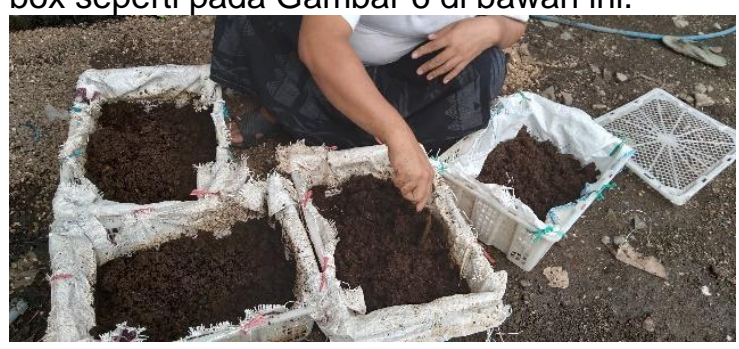

Gambar 6. Perkembangan cacing tanah dari 2 box menjadi 4 box

Hal ini dikarenakan 1 box di awal banyak yang mati akibat lama dalam proses pengiriman dan faktor yang kedua yaitu cacing tidak sesuai dengan media awal yaitu dengan menggunakan bekas budidaya jamur.

\section{SIMPULAN DAN SARAN}

Berdasarkan data hasil kegiatan PKM yang telah dilakukan dapat disimpulkan bahwa keterampilan berbudidaya cacing tanah sudah dilakukan dan pihak mitra mampu melaksanakan kegiatan tersebut meliputi persiapan media, pembuatan pakan, perawatan. Selain itu, hampir semua pengurus dari pihak mitra menyatakan bahwa pelatihan budidaya cacing tanah ini bermanfaat

Adapun hal-hal yang dapat disarankan antara lain yaitu perlu pendampingan yang lebih intensif kepada peserta pelatihan budidaya cacing tanah dan menambah waktu pelaksanaan budidaya cacing tanah sehingga lebih bisa dilihat dampak kegiatan terhadap perekonomian masyarakat.

\section{UCAPAN TERIMAKASIH}

Terimakasih sebesar-besarnya kepada

1. Ibu Rektor UNU NTB yang sudah memberikan dukunga penuh sehingga kami bisa melaksanakan kegiatan PKM tentang budidaya cacing tanah.

2. LPM UNU NTB yang sudah membantu kami mulai dari penyusunan proposal PKM, monitoring kegiatan PKM, sampai denga pelaporan PKM. 
3. Pihak mitra PKM yakni Yayasan Daarul Hufadz Al-Amin Wates yang sudah menerima dan menyambut dengan sangat baik pelaksanakan PKM.

\section{DAFTAR RUJUKAN}

Achmad Mubarok, Drh. Lili Zalizar, MS (2003). Budidaya Cacing Tanah Sebagai Usaha Alternatif di Masa Krisis Ekonomi. Jurnal Dedikasi Volume. 1 (1).

Andi Rahmad Rahim. (2018). Pemanfaatan Limbah Tambak Ikan Untuk Budidaya Cacing Tanah Lumbricus Rubellus. Jurnal Perikanan Pantura. 1(2). 1-8.

Diana Chilmawati, dkk. (2014). Budidaya Cacing Tanah Sebagai Sumber Pakan Alternatif Dalam Pemeliharaan Lele Dumbo Di Pondok Pesatren Hidayatullah, Gedawang, Semarang. Jurnal Saintek Perikanan. 9(2). 49-52.

G Subowo, dkk. (2008). Prospek Cacing Tanah Untuk Pengembangan Teknologi Resapan Biologi di Lahan Kering. Jurnal Litbang Pertanian. 27(4). 146150

Rusmini, dkk. (2016). Pelatihan Budidaya Cacing Tanah (Lumbricus Rubellus) Bagi Para Tani Desa Sumberdukun, Ngariboyo, Magetan. ABDI. 1(2) . 114120.

Suminto, Diana Chilmawati. (2016). Prosiding Seminar Nasional Tahunan Ke-V HasilHasil Penelitian Perikanan dan Kelautan.

Umi Fadilah, Joko Waluyo, Wahju Subchan. (2017). Efektiftas Cacing Tanah Dalam Degradasi Karbon Organic Sampah Sayur Pasar Tanjug Jember. BERKALA SAINSTEK 2017, V (1): 1-6. 